\title{
Bottling Spring Water from a Serbian Mountain
}

\section{Slavica Ćirić*, Božidar Milošević, Zvonko Spasić, Zoran Ilić, Danijela Prodanović}

University of Priština, Faculty of Agriculture, Kopaonička bb, 38219 Lešak, Serbia

Received: 2 May 2017

Accepted: 11 July 2017

\begin{abstract}
The aim of this study was to examine the possibilities of bottling the water from four sources (in total 10 springs) on Jastrebac Mountain in central Serbia. In the water samples, the following parameters were determined:

- Physico-chemical parameters - temperature and solids content (total, dissolved and suspended), turbidity, $\mathrm{pH}$, conductivity, hardness (as $\mathrm{CaCO}_{3}$ ), alkalinity (as $\mathrm{CaCO}_{3}$ ), oxygen concentration and saturation, concentrations of $\mathrm{Al}, \mathrm{Ca}, \mathrm{Mg}, \mathrm{Fe}, \mathrm{F}^{-}, \mathrm{Cl}^{-}$, and $\mathrm{SO}_{4}^{2-}$, inorganic nitrogen content $\left(\mathrm{NH}_{4}^{+}, \mathrm{NO}_{2}^{-}\right.$, and $\mathrm{NO}_{3}^{-}$), total phosphorus and orthophosphates content $\left(\mathrm{PO}_{4}^{3-}\right)$, and the content of organic compounds as concentrations of $\mathrm{KMnO}_{4}$ and $\mathrm{UV}$ extinction.

- Microbiological parameters - total count of aerobic mesophilic bacteria, count of coliform bacteria, and the presence of faecal indicators (faecal coliforms, faecal streptococci, and sulphitereducing clostridia).

- Biological parameters.

Based on the obtained values of the examined parameters and their ratings, five springs out of 10 tested could be considered for bottling. The values of the parameters of these springs were in compliance with current regulations for drinking water. Also, these springs had a significantly higher quality of water compared to the one of the most used bottled water in Serbia. Other springs had a considerably poorer quality of water due to exposure to the negative anthropogenic effects, which was particularly manifested in the form of the excessive count of total bacteria, the presence of the indicators of faecal contamination, and the presence of suspended solids.
\end{abstract}

Keywords: drinking water, spring water, bottling, physico-chemical parameters, microbiological parameters, biological parameters, ratings

\section{Introduction}

A fundamental requirement of good health and normal functioning of humans and animals is a sufficient

*e-mail: slavica.ciric@mts.rs

intake of water [1]. The most important characteristic of drinking water in terms of safety for human consumption is its quality [2]. This means that drinking water must not contain such harmful ingredients as pathogenic microorganisms, toxic substances, physical and chemical residuals, and undesirable organoleptic properties such as odor, color, or taste. The United Nations has announced 
that "safe and clean drinking water is a human right essential to the full enjoyment of life and all other human rights" [3]. Drinking water quality is determined by physical (temperature, color, taste, odor, turbidity, solids), chemical (inorganic minerals, $\mathrm{pH}$, alkalinity, acidity, hardness, total dissolved solids, conductivity, radionuclides, phosphates, nitrates, organic materials, dissolved oxygen, etc.), microbiological (heterotrophic plate count, total coliforms, faecal coliforms - Escherichia coli, faecal streptococci, clostridia, viruses), and biological (blue-green algae, fungi, protozoa) parameters.

Drinking water is treated in cases where the source is not of satisfactory quality that can provide safe water [4]. Water that is not treated, such as natural mineral water and spring water, do not pass any treatment or undergo primary disinfection only [4-5].

The growth of the global human population has led to a dramatic increase of the need for safe and highquality drinking water [6]. This applies particularly to bottled water, which has become extremely popular in recent decades [7-8] because of its convenience, safety, and quality - despite its high price. In addition, bottled water plays a significant role as a very important product in some areas of the world where groundwater is scarce [9] or, in the case of many developing countries, where the public water supply is not potable [10]. Tests at the international level have shown that people prefer bottled water because they assume that it is safer and of better quality than water from public water supplies [11-14]. Francisco [15] showed that public distrust of the safety and quality of the municipal water supply is the main reason for the population's preference for bottled water as the primary drinking water source. The majority of the global market for bottled water is in North America and Europe [7].
The major types of bottled water are: mineral, spring, purified, well, artesian, and sparkling bottled. Spring water is "water extracted from an underground formation from which water flows naturally to the earth's surface. This must be collected only at the spring or through a borehole tapping the underground formation feeding the spring. The water must have all the physical properties before treatment and be of the same quality and composition as the water that naturally flows to the surface of the earth" [16].

Due to the increasing need for high-quality drinking water and the growing consumption of bottled water, the aim of this study was to examine the possibilities for bottling some spring waters on Jastrebac Mountain in central Serbia. The results were compared with current legislation on the quality of bottled water and drinking water, as well as with the quality of the most present bottled water on the Serbian market, called Vlasinska Rosa.

\section{Materials and Methods}

\section{Study Area}

In late spring and early summer of 2016 we tested the water quality of four important springs on Jastrebac

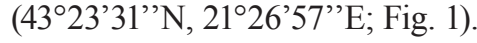

The following springs were examined:

- The spring under Velika Ravan is at $750 \mathrm{~m}$ altitude and was capped once for the supply of a villa. In the capping, which is very poorly constructed, the water of the much smaller spring at Velika Ravan was introduced by pipeline. This spring is at a higher altitude and it is marked as Velika Ravan 1, while

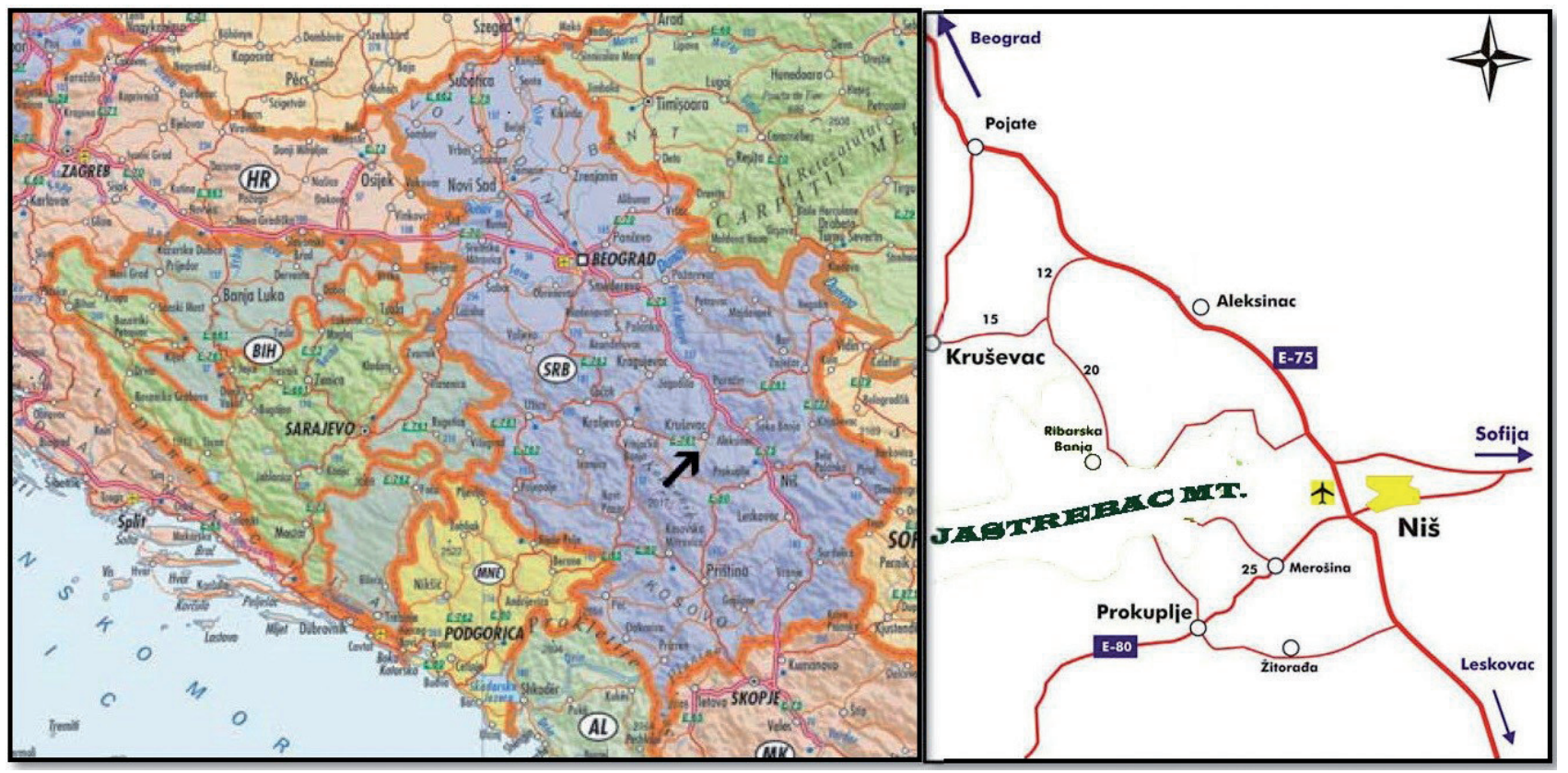

Fig. 1. Geographic location of Jastrebac Mt., Serbia. 
the primary, much larger spring is marked as Velika Ravan 2. Close to the main spring, the two forest roads converge. One of these roads leads to the western part of Jastrebac, and the second climbs to the ridge of the mountain horst. The immediate and wider area of springs is exposed to the negative anthropogenic effects due to logging.

- The second tested spring is Majorova Česma, located in the Grand Canal, and the saddle is about $880 \mathrm{~m}$ high, which is in a relatively inaccessible mountain ridge and represents the fastest gateway to the southern slopes of Jastrebac, or to the Toplica River. Majorova Česma represents a permanent spring of varied flow that is significantly reduced during the summer. As a favorite resort, the area around Majorova Česma is more damaged than at Velika Ravan.

- The spring area of Ribna River, a tributary of the Lomnička River, is presented by a complex system of springs under the western part of Stracimir, at about $950 \mathrm{~m}$ of altitude. Located in very inaccessible terrain, the eight springs used to supply most of the villas on Jastrebac were tapped in 1967. Seven springs flow into the common collecting chamber, while the eighth, which is located a little to the east of the first seven, is introduced into the first end chamber. As people rarely come to the region of the springs, that part of the mountain has slowly been transformed into the forest, making it difficult to locate the individual springs located near the both banks of the Ribna River. Therefore, the flows in the collection chamber are marked by the scheme shown in Fig. 2.

- On the Velika Sokolovica, which is also the part of the Stracimir, at an altitude of about $950 \mathrm{~m}$, two springs supplying the villages of Buci and Lomnica, are capped. The water was sampled in the first breaking chamber, at $80 \mathrm{~m}$ of altitude under the bigger spring (pipeline $\varnothing 100 \mathrm{~mm}, 10 \mathrm{bar}$ ). That part of the mountain is also inaccessible.

Along with the water of springs on Jastrebac, chemical and microbiological quality of the bottled water were tested. According to the location of the source in Jakov Do on Čemernik Mountain (southeastern Serbia), Vlasinska Rosa should be the best-quality water in Serbia. The water from Čemernik spring, as well as the water from Jastrebac springs, belongs to the oligomineral waters.

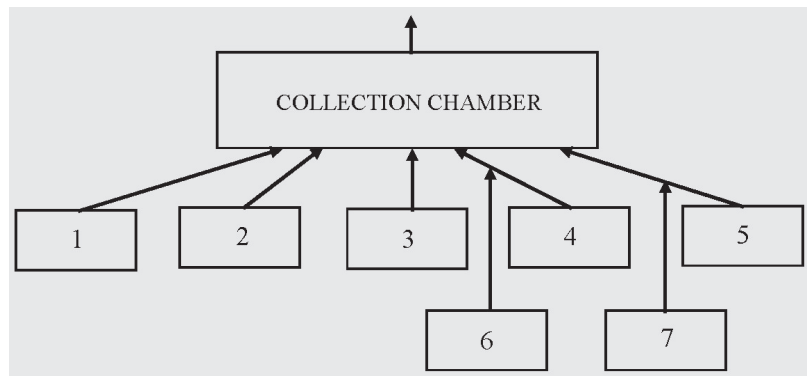

Fig. 2. Schematic representation of the Ribna River springs

\section{Physico-Chemical Analysis of Water}

Physical and chemical parameters of water were tested as follows: temperature $\left({ }^{\circ} \mathrm{C}\right)$; the solids content (total, dissolved, and suspended; mg/l); turbidity (NTU); $\mathrm{pH}$; conductivity $(\mu \mathrm{S} / \mathrm{cm})$; hardness (as $\mathrm{CaCO}_{3}, \mathrm{mg} / \mathrm{l}$ ); alkalinity (as $\left.\mathrm{CaCO}_{3}, \mathrm{mg} / \mathrm{l}\right)$; oxygen concentration (mg/l) and saturation $(\%)$; concentrations $(\mathrm{mg} / \mathrm{l})$ of aluminium $(\mathrm{Al})$, calcium $(\mathrm{Ca})$, manganese $(\mathrm{Mg})$, iron $(\mathrm{Fe})$, fluoride $\left(\mathrm{F}^{-}\right)$, chloride $\left(\mathrm{Cl}^{-}\right)$, and sulphate $\left(\mathrm{SO}_{4}^{2-}\right)$; content of inorganic nitrogen (ammonium - $\mathrm{NH}_{4}^{+}$, nitrite $-\mathrm{NO}_{2}$, and nitrate $\left.-\mathrm{NO}_{3}^{-} ; \mathrm{mg} / \mathrm{l}\right)$; content of total phosphorus and orthophosphates $\left(\mathrm{PO}_{4}^{3-}\right), \mathrm{mg} / \mathrm{l}$; and content of organic compounds as concentrations of $\mathrm{KMnO}_{4}(\mathrm{mg} / \mathrm{l})$ and $\mathrm{UV}$ extinction $/ \mathrm{m}$. All of the above parameters were tested by the American standard methods [4].

\section{Microbiological Analysis of Water}

Out of microbiological parameters, the total count of aerobic mesophilic bacteria was studied, as this parameter is the most common cause of inadequate drinking water quality [17-18]. These bacteria were examined by the cultivation method on two standard media: plate count agar (PCA) and reasoner's 2 agar (R2A). Currently, in Serbia and in many countries in the world, PCA is the official medium for testing the total count of bacteria, but since it detects a statistically significantly lower count of bacteria than R2A medium [19-20], it is the matter of the moment when PCA will be replaced by R2A medium according to the official regulations. All around the world, R2A medium is used for testing bottled water as standard medium [21].

The total count of coliform bacteria in $100 \mathrm{ml}$ of the water sample was determined as the most probable number by MPN method, in lactose Andrade peptone water. After incubation for 48 hours at $37^{\circ} \mathrm{C}$ and subcultivation on the eosine methylene blue agar, re-incubation for 24 hours at $37^{\circ} \mathrm{C}$ was carried out in order to detect the typical colonies.

The count of faecal coliform bacteria was determined by membrane filtration. Sterile filter papers were placed one by one using sterile forceps in three Petri dishes. On the surface of each filter paper $2 \mathrm{ml}$ of sterile m-FC broth (Oxoid, UK) was added. Then, 0.1, 1, 5, and $15 \mathrm{ml}$ of water sample were filtered and filters were placed on the appropriate filter papers. Petri dish lids were attached to the lower parts by parafilm to avoid drying, and were then incubated at $44.5^{\circ} \mathrm{C}$ for 24 hours. After the incubation, the blue colored colonies (Escherichia coli) were counted. The number was recalculated for $100 \mathrm{ml}$ of water and recorded as the count of faecal coliforms per $100 \mathrm{ml}$ of water.

The count of faecal streptococci was determined by membrane filtration. The water sample volumes of $0.1,1,5$, and $15 \mathrm{ml}$ were filtered. Each filter was placed on sterile KF streptococcus agar (Oxoid, UK) that had previously been poured into Petri dishes. The dishes were then turned on their lids and incubated at $37^{\circ} \mathrm{C}$ for 
48 hours. After incubation, all the red and pink colonies were counted and the number was recalculated for $100 \mathrm{ml}$ of water and recorded as the count of faecal streptococci per $100 \mathrm{ml}$ of water.

The content of sulphitereducing anaerobes (Clostridium sp.) was determined by treating a water sample with the temperature of $78^{\circ} \mathrm{C}$ and then inoculating in a sulphite agar (Oxoid, UK). After incubation at $37^{\circ} \mathrm{C}$ for 24 hours, the count of sulphitereducing anaerobic bacteria was determined as the most probable number, recalculated for $100 \mathrm{ml}$ of water and recorded as the count of sulphitereducing clostridia per $100 \mathrm{ml}$ of water.
Further identification of isolates was performed on the basis of the morphology of bacterial colonies and biochemical reactions such as coagulase reaction, indole, urease, methyl red, Voges-Proskauer, citrate utilization, and sugar fermentation, and confirmed by using the API 20E identification system (bio-Mérieux, France).

\section{Biological Analysis of Water}

Biological tests were carried out under a light microscope with a magnification of 200x and 400x. Total fungal viable counts were recorded in all samples in the following way. One hundred milliliters of each sample was

Table 1. Physico-chemical parameters of of Velika Ravan 1, Velika Ravan 2, and Majorova Česma spring water.

\begin{tabular}{|c|c|c|c|c|}
\hline & & & Spring & \\
\hline & & Velika Ravan 1 & Velika Ravan 2 & Majorova Česma \\
\hline & $1 / \mathrm{s}$ & 0.006 & 0.430 & $0.883 * / 2 * *$ \\
\hline THW tale & $1 / \mathrm{min}$ & 0.341 & 25.690 & $53 * / 120 * *$ \\
\hline Temperature & $\left({ }^{\circ} \mathrm{C}\right)$ & 10.25 & 8.00 & 7.25 \\
\hline & Total $\left(104^{\circ} \mathrm{C}\right)$ & 86.0 & 92.0 & 57.0 \\
\hline Solids (mg/l) & Suspended $\left(104^{\circ} \mathrm{C}\right)$ & 1.440 & 0.520 & 0.360 \\
\hline & Dissolved $\left(180^{\circ} \mathrm{C}\right)$ & 56.0 & 54.0 & 40.0 \\
\hline & NTU) & 1.50 & 0.25 & 0.23 \\
\hline Con & $(\mu \mathrm{S} / \mathrm{cm})$ & 111.4 & 120.6 & 100.1 \\
\hline & & 7.53 & 6.71 & 5.95 \\
\hline Hardn & $\mathrm{CO}_{3}(\mathrm{mg} / \mathrm{l})$ & 60.0 & 34.0 & 23.0 \\
\hline Alkalir & $\mathrm{CO}_{3}(\mathrm{mg} / \mathrm{l})$ & 20.0 & 17.5 & 7.5 \\
\hline & conc. $(\mathrm{mg} / \mathrm{l})$ & 9.90 & 10.36 & 9.48 \\
\hline олудй & sat. $(\%)$ & 94.9 & 94.3 & 82.6 \\
\hline & & 0.000 & 0.000 & 0.000 \\
\hline & & 16.830 & 10.420 & 7.613 \\
\hline & & 0.000 & 0.000 & 0.000 \\
\hline & & 0.166 & 0.040 & 0.000 \\
\hline & & 0.099 & 0.080 & 0.068 \\
\hline & & 6.39 & 6.39 & 4.26 \\
\hline & & 12.46 & 13.84 & 8.35 \\
\hline & $\mathrm{NH}_{4}^{+}$ & 0.000 & 0.000 & 0.000 \\
\hline Inorganic nitrogen $(\mathrm{mg} / \mathrm{l})$ & $\mathrm{NO}_{2}^{-}$ & 0.000 & 0.000 & 0.000 \\
\hline & $\mathrm{NO}_{3}^{-}$ & 2.810 & 2.410 & 3.065 \\
\hline Phosphorus (moll) & $\mathrm{PO}_{4}^{3-}$ & 0.012 & 0.010 & 0.030 \\
\hline & total & 0.021 & 0.020 & 0.033 \\
\hline Oronis compound & as $\mathrm{KMnO}_{4}(\mathrm{mg} / \mathrm{l})$ & 7.04 & 3.84 & 2.49 \\
\hline & UV extinct./m & 3.10 & 1.70 & 1.45 \\
\hline
\end{tabular}

*flow rate through the fountain, **flow rate of the spring 
filtered through cellulose nitrate filter $47 \mathrm{~mm}$ in diameter and $0.45 \mu \mathrm{m}$ of pore diameter. The filter was transferred to a petri dish containing sterilized sabouraud dextrose agar (SDA) supplemented with chloramphenicol $50 \mathrm{mg} / 1$ and gentamycine $25 \mathrm{mg} / \mathrm{l}$ after autoclaving [22]. The plates were incubated for $5-7$ days at $28^{\circ} \mathrm{C}$. After incubation, the number of colonies was recorded and fungal isolates were subcultured separately for identification. Fungi were identified to generic level according to morphological features with the assistance of relevant literature [23-24].

All analyses were carried out in the chemical and microbiological laboratories of the Drinking Water Treatment Plant in Majdevo, near the central Serbian town of Kruševac.

\section{Results and Discussion}

The results of physico-chemical analysis of tested springs and bottled water are shown in Tables 1 and 2 .

Analysis of physico-chemical parameters showed that the water of all springs was of excellant quality, except the one with the inconsiderable flow rate (Velika Ravan 1). Within this high quality there were significant differences, so that the springs were getting better at higher altitude and more inaccesible. On the other hand, it is indicative that the larger flow rate, i.e., the more abundant spring, was for the most part positively correlated with better chemical quality.

Table 2. Physico-chemical parameters of Ribna River and Velika Sokolovica spring water, and Vlasinska Rosa bottled water.

\begin{tabular}{|c|c|c|c|c|c|c|c|c|c|}
\hline \multirow{2}{*}{\multicolumn{2}{|c|}{ Parameter }} & \multicolumn{5}{|c|}{ Ribna River springs } & \multicolumn{2}{|c|}{$\begin{array}{c}\text { Velika Sokolovica } \\
\text { springs }\end{array}$} & \multirow{2}{*}{$\begin{array}{l}\text { Vlasinska } \\
\text { Rosa }\end{array}$} \\
\hline & & 1 & 2 & 3 & 4 & 5 & 1 & 2 & \\
\hline \multirow{2}{*}{ Flow rate } & $1 / \mathrm{s}$ & 1.358 & 1.425 & 0.183 & 0.037 & 0.019 & 10.750 & 0.850 & - \\
\hline & $1 / \min$ & 81.500 & 85.500 & 11.000 & 2.230 & 1.120 & 645.000 & 50.970 & - \\
\hline Temperature & $\left({ }^{\circ} \mathrm{C}\right)$ & 7.00 & 7.00 & 8.50 & 9.80 & 9.80 & 7.00 & 8.00 & - \\
\hline \multirow{3}{*}{ Solids (mg/l) } & Total $\left(104^{\circ} \mathrm{C}\right)$ & 92.0 & 91.9 & 90.0 & 87.0 & 102.0 & 71.5 & 65.5 & 42.00 \\
\hline & Suspended $\left(104^{\circ} \mathrm{C}\right)$ & 0.190 & 0.170 & 0.162 & 0.200 & 0.160 & - & - & 0.120 \\
\hline & Dissolved $\left(180^{\circ} \mathrm{C}\right)$ & 69.0 & 71.0 & 70.2 & 77.8 & 94.0 & 62.5 & 60.5 & 10.00 \\
\hline \multicolumn{2}{|c|}{ Turbidity (NTU) } & 0.075 & 0.095 & 0.095 & 0.24 & 0.14 & 0.18 & 0.22 & 0.16 \\
\hline \multicolumn{2}{|c|}{ Conductivity $(\mu \mathrm{S} / \mathrm{cm})$} & 82.9 & 84.4 & 87.3 & 83.7 & 73.4 & 85.8 & 79.6 & 72.5 \\
\hline \multicolumn{2}{|c|}{$\mathrm{pH}$} & 6.36 & 6.46 & 6.55 & 6.61 & 6.26 & 6.93 & 6.60 & 7.69 \\
\hline \multicolumn{2}{|c|}{ Hardness as $\mathrm{CaCO}_{3}(\mathrm{mg} / \mathrm{l})$} & 22.3 & 29.0 & 30.2 & 29.4 & 23.5 & 27.7 & 23.5 & 30.0 \\
\hline \multicolumn{2}{|c|}{ Alkalinity as $\mathrm{CaCO}_{3}(\mathrm{mg} / \mathrm{l})$} & 13.3 & 16.9 & 17.6 & 14.7 & 13.7 & 15.0 & 15.0 & 27.5 \\
\hline \multirow{2}{*}{ Oxygen } & conc. $(\mathrm{mg} / \mathrm{l})$ & 9.75 & 10.23 & 9.92 & 9.84 & 9.35 & 13.02 & 10.39 & - \\
\hline & sat. $(\%)$ & 91.6 & 90.5 & 90.3 & 92.3 & 87.9 & 114.2 & 92.6 & - \\
\hline \multicolumn{2}{|c|}{$\mathrm{Al}(\mathrm{mg} / \mathrm{l})$} & 6.511 & 7.707 & 7.374 & 7.604 & 7.214 & 10.320 & 8.810 & 0.014 \\
\hline \multicolumn{2}{|c|}{$\mathrm{Ca}(\mathrm{mg} / \mathrm{l})$} & 0.000 & 0.000 & 0.000 & 0.021 & 0.021 & 0.010 & 0.000 & 11.020 \\
\hline \multicolumn{2}{|c|}{$\mathrm{Mn}(\mathrm{mg} / \mathrm{l})$} & 0.000 & 0.000 & 0.000 & 0.000 & 0.000 & 0.000 & 0.000 & 0.000 \\
\hline \multicolumn{2}{|c|}{$\mathrm{Fe}(\mathrm{mg} / \mathrm{l})$} & 0.000 & 0.000 & 0.000 & 0.030 & 0.033 & 0.000 & 0.000 & 0.000 \\
\hline \multicolumn{2}{|c|}{$\mathrm{F}^{-}(\mathrm{mg} / \mathrm{l})$} & 0.068 & 0.059 & 0.064 & 0.069 & 0.060 & 0.006 & 0.009 & 0.095 \\
\hline \multicolumn{2}{|c|}{$\mathrm{Cl}^{-}(\mathrm{mg} / \mathrm{l})$} & 4.97 & 4.97 & 4.97 & 4.97 & 4.97 & 4.70 & 4.44 & 5.68 \\
\hline \multicolumn{2}{|c|}{$\mathrm{SO}_{4}^{2-}(\mathrm{mg} / \mathrm{l})$} & 9.55 & 9.87 & 9.11 & 7.885 & 7.66 & 8.200 & 9.04 & 3.63 \\
\hline \multirow{3}{*}{$\begin{array}{l}\text { Inorganic nitrogen } \\
\qquad(\mathrm{mg} / \mathrm{l})\end{array}$} & $\mathrm{NH}_{4}^{+}$ & 0.000 & 0.000 & 0.000 & 0.000 & 0.000 & 0.000 & 0.000 & 0.000 \\
\hline & $\mathrm{NO}_{2}^{-}$ & 0.000 & 0.000 & 0.000 & 0.000 & 0.000 & 0.000 & 0.000 & 0.000 \\
\hline & $\mathrm{NO}_{3}^{-}$ & 2.430 & 2.442 & 2.463 & 2.453 & 2.744 & 2.599 & 1.955 & 0.362 \\
\hline \multirow{2}{*}{ Phosphorus (mg/l) } & $\mathrm{PO}_{4}^{3-}$ & 0.009 & 0.008 & 0.008 & 0.003 & 0.016 & 0.001 & 0.002 & 0.040 \\
\hline & total & 0.010 & 0.009 & 0.009 & 0.005 & 0.019 & 0.003 & 0.004 & 0.042 \\
\hline \multirow{2}{*}{ Organic compounds } & as $\mathrm{KMnO}_{4}(\mathrm{mg} / \mathrm{l})$ & 1.58 & 1.58 & 1.52 & 2.22 & 2.06 & 1.89 & 1.89 & 2.49 \\
\hline & UV extinct./m & 1.30 & 1.45 & 1.65 & 1.75 & 1.72 & 0.73 & 0.60 & - \\
\hline
\end{tabular}


Table 3. Results of microbiological analysis of Velika Ravan and Majorova Česma spring water.

\begin{tabular}{|c|c|c|c|c|c|c|}
\hline \multirow{2}{*}{ Parameter } & \multirow{2}{*}{ Medium } & \multirow{2}{*}{\multicolumn{2}{|c|}{ Incubation conditions }} & \multicolumn{3}{|c|}{ Spring } \\
\hline & & & & Velika Ravan 1 & Velika Ravan 2 & Majorova Česma \\
\hline \multirow{16}{*}{$\begin{array}{l}\text { Total count } \\
\text { of aerobic } \\
\text { mesophilic } \\
\text { bacteria } \\
(\mathrm{CFU} / \mathrm{ml})\end{array}$} & \multirow{8}{*}{$\begin{array}{c}\text { Plate Count } \\
\text { Agar }\end{array}$} & \multirow{2}{*}{$37^{\circ} \mathrm{C}$} & $48 \mathrm{~h}$ & 10 & 1 & 1 \\
\hline & & & 7 days & 39 & 2 & 2 \\
\hline & & \multirow{3}{*}{$20^{\circ} \mathrm{C}$} & $48 \mathrm{~h}$ & 91 & 5 & 4 \\
\hline & & & 7 days & 800 & 28 & 21 \\
\hline & & & 30 days & 1,430 & 51 & 40 \\
\hline & & \multirow{3}{*}{$8^{\circ} \mathrm{C}$} & $48 \mathrm{~h}$ & 6 & 3 & 3 \\
\hline & & & 7 days & 29 & 10 & 26 \\
\hline & & & 30 days & 920 & 12 & 40 \\
\hline & \multirow{8}{*}{ R2A agar } & \multirow{2}{*}{$37^{\circ} \mathrm{C}$} & $48 \mathrm{~h}$ & 145 & 2 & 2 \\
\hline & & & 7 days & 280 & 3 & 2 \\
\hline & & \multirow{3}{*}{$20^{\circ} \mathrm{C}$} & $48 \mathrm{~h}$ & 351 & 10 & 22 \\
\hline & & & 7 days & 2,330 & 64 & 148 \\
\hline & & & 30 days & 5,350 & 105 & 251 \\
\hline & & \multirow{3}{*}{$8^{\circ} \mathrm{C}$} & $48 \mathrm{~h}$ & 223 & 5 & 27 \\
\hline & & & 7 days & 1,070 & 25 & 128 \\
\hline & & & 30 days & 2,190 & 39 & 149 \\
\hline \multirow{3}{*}{$\begin{array}{l}\text { Coliforms } \\
\text { (per } 100 \mathrm{ml})\end{array}$} & \multicolumn{3}{|c|}{ Total } & 4 & 0 & 0 \\
\hline & \multicolumn{3}{|c|}{ Faecal } & 2 (Escherichia coli) & 0 & 0 \\
\hline & \multicolumn{3}{|c|}{ Non-faecal } & $\begin{array}{l}2 \text { (Citrobacter freundii, } \\
\text { Klebsiella pneumoniae) }\end{array}$ & 0 & 0 \\
\hline \multicolumn{4}{|c|}{ Faecal streptococci (per 100 ml) } & 1 (Enterococcus faecalis) & 0 & 0 \\
\hline \multicolumn{4}{|c|}{ Sulphitereducing clostridia (per $100 \mathrm{ml}$ ) } & 7 & 2 & 0 \\
\hline \multicolumn{4}{|c|}{ Isolated bacteria (per $100 \mathrm{ml}$ ) } & $\begin{array}{l}\text { G- bacilli (4), Bacillus spp. } \\
\text { (2) }\end{array}$ & $\begin{array}{c}\text { G- bacilli (3), } \\
\text { Bacillus spp. (2) }\end{array}$ & $\begin{array}{l}\text { G- bacilli (1), } \\
\text { Bacillus spp. (2) }\end{array}$ \\
\hline
\end{tabular}

The results of microbiological analysis of tested springs and bottled water are shown in Tables 3 and 4 .

Since drinking water must not contain coliforms, faecal streptococci, and sulphitereducing clostridia, in the analysis of microbiological parameters the emphasis was placed on the total content of the aerobic mesophilic bacteria. Considering that the microorganisms, which are few in clean springs, multiply during the storage of bottled water, their contents in the springs of Ribna River and Velika Sokolovica were examined not only immediately after sampling, but after one month of sitting in sealed sterile bottles at $12^{\circ} \mathrm{C}$ with very little air.

In the immediate determination of microorganisms, as well as in the case of chemical quality, the higher flow rate was generally positively correlated with better microbiological quality of water. However, the content of microorganisms after a month of standing showed a more complicated picture of water quality (Table 5). FalconeDias et al. [25] stated that spring waters are not free of bacteria, and counts of $10^{4}-10^{5} \mathrm{cfu} / \mathrm{ml}$ can be reached within a few days after bottling. Duranceau et al. [26] showed that the abundance of heterotrophs increased rapidly after 3 to 7 days of bottling. It was also shown that the most common cause of poor microbiological quality of bottled water was the increased content of aerobic mesophilic bacteria [21, 27].

Biological analysis of water gave the simplest picture of water quality. From biological material we found only fungi, the parts of detritus (i.e., the remains of dead plants), and the pollen grains of higher plants (Table 6). Out of fungi we found the fragments of hyphae that contained several cells whose origin and affiliation were not possible to determine, and the conidia of Fungi imperfecti. All founded conidia belonged to the obligate or facultative aquatic species.

For the purpose of unification and easier comparisons, the number is expressed as units per hectolitre $(\mathrm{U} / \mathrm{hl})$, or units per litre (U/1).

From a biological point of view, the quality of water was primarily directly proportional to the inaccessibility 
Table 4. Results of microbiological analysis of Ribna River and Velika Sokolovica spring water, and Vlasinska Rosa bottled water.

\begin{tabular}{|c|c|c|c|c|c|c|c|c|c|c|c|}
\hline \multirow[t]{2}{*}{ Parameter } & \multirow[t]{2}{*}{ Medium } & \multirow{2}{*}{\multicolumn{2}{|c|}{$\begin{array}{l}\text { Incubation } \\
\text { conditions }\end{array}$}} & \multicolumn{5}{|c|}{ Ribna River springs } & \multicolumn{2}{|c|}{$\begin{array}{c}\text { Velika } \\
\text { Sokolovica } \\
\text { springs }\end{array}$} & \multirow{3}{*}{$\begin{array}{c}\text { Vlasinska } \\
\text { Rosa } \\
308\end{array}$} \\
\hline & & & & \multirow[t]{2}{*}{1} & \multirow{2}{*}{$\begin{array}{l}2 \\
0\end{array}$} & \multirow{2}{*}{$\begin{array}{l}3 \\
0\end{array}$} & \multirow{2}{*}{$\begin{array}{l}4 \\
5\end{array}$} & \multirow{2}{*}{$\begin{array}{l}5 \\
8\end{array}$} & 1 & 2 & \\
\hline \multirow{16}{*}{$\begin{array}{c}\text { Total count } \\
\text { of aerobic } \\
\text { mesophilic } \\
\text { bacteria } \\
(\mathrm{CFU} / \mathrm{ml})\end{array}$} & \multirow{8}{*}{$\begin{array}{l}\text { Plate } \\
\text { Count } \\
\text { Agar }\end{array}$} & \multirow{2}{*}{$37^{\circ} \mathrm{C}$} & $48 \mathrm{~h}$ & & & & & & 1 & 0 & \\
\hline & & & 7 days & 0 & 0 & 0 & 6 & 13 & 1 & 1 & 343 \\
\hline & & \multirow{3}{*}{$20^{\circ} \mathrm{C}$} & $48 \mathrm{~h}$ & 0 & 0 & 0 & 56 & 49 & 3 & 4 & 3,210 \\
\hline & & & 7 days & 2 & 1 & 1 & 168 & 143 & 10 & 14 & 9,950 \\
\hline & & & 30 days & 4 & 1 & 3 & 240 & 155 & 16 & 23 & - \\
\hline & & \multirow{3}{*}{$8^{\circ} \mathrm{C}$} & $48 \mathrm{~h}$ & 0 & 0 & 0 & 21 & 33 & 1 & 3 & 654 \\
\hline & & & 7 days & 2 & 3 & 1 & 84 & 95 & 10 & 15 & 2,610 \\
\hline & & & 30 days & 2 & 3 & 2 & 150 & 155 & 25 & 27 & - \\
\hline & \multirow{8}{*}{$\begin{array}{l}R 2 A \\
\text { agar }\end{array}$} & \multirow{2}{*}{$37^{\circ} \mathrm{C}$} & $48 \mathrm{~h}$ & 0 & 0 & 0 & 9 & 10 & 1 & 1 & 4,425 \\
\hline & & & 7 days & 0 & 0 & 0 & 18 & 14 & 1 & 1 & 5,615 \\
\hline & & \multirow{3}{*}{$20^{\circ} \mathrm{C}$} & $48 \mathrm{~h}$ & 0 & 0 & 0 & 45 & 36 & 4 & 5 & 8,696 \\
\hline & & & 7 days & 2 & 2 & 3 & 300 & 219 & 24 & 27 & 60,000 \\
\hline & & & 30 days & 4 & 6 & 3 & 320 & 229 & 35 & 39 & - \\
\hline & & \multirow{3}{*}{$8^{\circ} \mathrm{C}$} & $48 \mathrm{~h}$ & 0 & 0 & 0 & 29 & 21 & 2 & 5 & 517 \\
\hline & & & 7 days & 3 & 3 & 1 & 221 & 145 & 18 & 31 & 3,735 \\
\hline & & & 30 days & 3 & 6 & 3 & 341 & 208 & 40 & 49 & - \\
\hline \multirow{3}{*}{$\begin{array}{l}\text { Coliforms } \\
(\mathrm{no} / 100 \mathrm{ml})\end{array}$} & \multicolumn{3}{|c|}{ Total } & 0 & 0 & 0 & 2 & 2 & 0 & 0 & 0 \\
\hline & \multicolumn{3}{|c|}{ Faecal } & 0 & 0 & 0 & 0 & $\begin{array}{c}1 \\
\text { (E. coli) }\end{array}$ & 0 & 0 & 0 \\
\hline & \multicolumn{3}{|c|}{ Non-faecal } & 0 & 0 & 0 & $\begin{array}{c}2 \\
(C . \\
\text { freundii, } K . \\
\text { pneumoniae }) \\
\end{array}$ & $\begin{array}{c}1(K . \\
\text { pneumoniae })\end{array}$ & 0 & 0 & 0 \\
\hline \multicolumn{4}{|c|}{ Faecal streptococci (per 100 ml) } & 0 & 0 & 0 & 0 & 0 & 0 & 0 & 0 \\
\hline \multicolumn{4}{|c|}{ Sulphitereducing clostridia (per $100 \mathrm{ml}$ ) } & 0 & 0 & 0 & 0 & 0 & 0 & 0 & 0 \\
\hline \multicolumn{4}{|c|}{ Isolated bacteria (per $100 \mathrm{ml}$ ) } & $\begin{array}{l}\text { Bacillus } \\
\text { spp. (2) }\end{array}$ & $\begin{array}{c}\text { Bacillus } \\
\text { spp. (2) }\end{array}$ & $\begin{array}{c}\text { G- bacilli } \\
\text { (2), } \\
\text { Bacillus spp. } \\
\text { (2) }\end{array}$ & $\begin{array}{l}\text { G- bacilli } \\
\text { (2), } \\
\text { Bacillusspp. } \\
\text { (2) }\end{array}$ & $\begin{array}{l}\text { G- bacilli } \\
\text { (2), } \\
\text { Bacillus spp. } \\
\text { (2) }\end{array}$ & $\begin{array}{l}\text { G- } \\
\text { bacilli } \\
(3)\end{array}$ & $\begin{array}{c}\text { G- } \\
\text { bacilli } \\
(2)\end{array}$ & G- bacilli \\
\hline
\end{tabular}

of the terrain, i.e., preservation of the ecosystem, and within the same terrain to the water flow rates.

Based on these preliminary tests, Velika Ravan and Majorova Česma can be instantly ruled out as a potential sources for bottling because of their evident degradation of quality by anthropogenic influences. In the cases where the physico-chemical parameters fully meet the statutory requirements, the presence of bacterial contaminants can make a drinking water source unsuitable for that purpose [28].

Physical, physico-chemical, and chemical analysis showed that the water from Jastrebac springs was similar to the water from Jakov Do, reflecting the same type of lithological substrate. On the other hand, the results of chemical analysis of the bottled water were very similar to the values declared on the bottle, except for the concentration of chloride, which was much higher than declared. The Ribna River sampling showed that the water was of uniform physical and chemical quality, i.e., that there were no significant fluctuations in the investigated parameters.

Microbiological tests gave very variable results in samples that were repeated and showed a different growth potential at different temperatures. It is also a very interesting phenomenon that the sources with lower content of bacteria at the time of sampling had more bacteria after one month of standing than those that were worse at the moment of sampling. This little-studied 
Table 5. Total count of aerobic mesophilic bacteria after one month standing in sealed bottles.

\begin{tabular}{|c|c|c|c|c|c|c|c|c|c|}
\hline \multirow{2}{*}{ Medium } & \multirow{2}{*}{\multicolumn{2}{|c|}{$\begin{array}{l}\text { Incubation } \\
\text { conditions }\end{array}$}} & \multicolumn{5}{|c|}{ Ribna River springs } & \multicolumn{2}{|c|}{ Velika Sokolovica springs } \\
\hline & & & 1 & 2 & 3 & 4 & 5 & 1 & 2 \\
\hline \multirow{4}{*}{$\begin{array}{l}\text { Plate Count } \\
\text { Agar }\end{array}$} & \multirow{2}{*}{$37^{\circ} \mathrm{C}$} & $48 \mathrm{~h}$ & 0 & 0 & 0 & 1 & 3 & 11 & 0 \\
\hline & & 7 days & 1 & 1 & 3 & 1 & 5 & 15 & 1 \\
\hline & $20^{\circ} \mathrm{C}$ & 7 days & 6,000 & 8,550 & 880 & 1,020 & 243 & 16,800 & 249 \\
\hline & $8^{\circ} \mathrm{C}$ & 7 days & 4,140 & 7,530 & 1,115 & 364 & 387 & 3,115 & 328 \\
\hline \multirow{4}{*}{$R 2 A$} & \multirow{2}{*}{$37^{\circ} \mathrm{C}$} & $48 \mathrm{~h}$ & 0 & 0 & 1 & 1 & 6 & 102 & 4 \\
\hline & & 7 days & 276 & 426 & 32 & 769 & 392 & 168 & 5 \\
\hline & $20^{\circ} \mathrm{C}$ & 7 days & 34,250 & 12,500 & 4,260 & 4,200 & 3,620 & 45,700 & 1,495 \\
\hline & $8^{\circ} \mathrm{C}$ & 7 days & 16,450 & 11,550 & 4,215 & 491 & 1,410 & 4,730 & 507 \\
\hline
\end{tabular}

phenomenon can be explained by the composition of the microbial community [29]. Most likely, the springs with the higher flow rate, due to the flow velocity, have meager resident microbial community, which mostly consists of $K$ strategists [30]. Also, because of the flow velocity these springs have a higher proportion of $r$ strategists in a microbial community, which are there facultatively. Relying on the rapid multiplication in the favourable environmental conditions at low intraspecies competition, $r$ strategists are blocked by the poor resources of the powerful springs, where they represent the initial colonizers, i.e., pioneers. However, during the standing at convenient temperature, $r$ strategists, exploiting all the available environmental resources reached the maximum possible number. Less abundant springs, due to the slower flow rate, had numerous microbial community and presented mostly $K$ strategists, which reproduced slowly, optimizing the consumption of scarce environmental

Table 6. Results of biological analysis.

\begin{tabular}{|c|c|c|c|c|c|}
\hline \multirow{2}{*}{\multicolumn{2}{|c|}{ Spring }} & \multirow{3}{*}{$\begin{array}{c}\text { Organisms } \\
\text { Fungi }\end{array}$} & \multicolumn{2}{|c|}{ Count } & \multirow{2}{*}{ Species } \\
\hline & & & $\mathrm{U} / \mathrm{hl}$ & $\mathrm{U} / 1$ & \\
\hline \multirow{5}{*}{$\begin{array}{l}\text { VELIKA } \\
\text { RAVAN }\end{array}$} & \multirow{3}{*}{1} & & 148,880 & 1489 & $\begin{array}{l}\text { Aspergillus sp., Fusarium sp., Cladosporium sp., Alternaria sp., } \\
\text { Curvularia sp., Ulocladium sp. }\end{array}$ \\
\hline & & Cormophytae & 500 & 5 & \\
\hline & & Pollen & 500 & 5 & \\
\hline & \multirow{2}{*}{2} & Fungi & 14,000 & 140 & Fusarium sp., Cladosporium sp., Alternaria sp., Ulocladium sp. \\
\hline & & Cormophytae & 250 & 2.5 & \\
\hline \multirow{2}{*}{\multicolumn{2}{|c|}{ MAJOROVA ČESMA }} & Fungi & 1,316 & 13 & $\begin{array}{l}\text { Aspergillus sp., Fusarium sp., Cladosporium sp., Alternaria sp., } \\
\text { Curvularia sp. }\end{array}$ \\
\hline & & Cormophytae & 120 & Q & \\
\hline \multirow{8}{*}{ RIBNA RIVER } & 1 & Fungi & 52 & $<1$ & Aspergillus sp., Fusarium sp. \\
\hline & 2 & Fungi & 105 & 1 & Aspergillus sp., Fusarium sp., Alternaria sp., Ulocladium sp. \\
\hline & 3 & Fungi & 520 & 5 & Aspergillus sp., Fusarium sp., Alternaria sp., Ulocladium sp. \\
\hline & \multirow{3}{*}{4} & Fungi & 2,816 & 28 & $\begin{array}{l}\text { Aspergillus sp., Fusarium sp., Wallemia sp., Alternaria sp., } \\
\text { Ulocladium sp. }\end{array}$ \\
\hline & & Cormophytae & 13 & $<1$ & \\
\hline & & pollen & 26 & $<1$ & \\
\hline & \multirow[t]{2}{*}{5} & Fungi & 6,980 & 70 & $\begin{array}{l}\text { Aspergillus sp., Fusarium sp., Cladosporium sp., Epicoccum sp., } \\
\text { Trichocladium sp., Alternaria sp., Curvularia sp. }\end{array}$ \\
\hline & & pollen & 20 & $<1$ & \\
\hline \multirow{2}{*}{$\begin{array}{c}\text { VELIKA } \\
\text { SOKOLOVICA }\end{array}$} & 1 & Fungi & 1,340 & 13 & Aspergillus sp., Alternaria sp. \\
\hline & 2 & Fungi & 970 & 10 & Alternaria sp. \\
\hline
\end{tabular}


resources. Therefore, in these springs a larger count of bacteria was detected, and how this community of $K$ strategists already have reached an optimal count, the count of these bacteria did not increase by standing, as was the case with the more abundant springs. On the other hand, the drastic differences in the content of bacteria in different batches of Vlasinska Rosa indicated that there were natural fluctuations of quantitative and qualitative microbial content of water, which remained visible after the water was standing in the bottles.

By the statistical analysis of the differences in the values of the parameters between the individual springs of Ribna River and Velika Sokolovica, it was impossible to single out the best source. Therefore, the springs were evaluated on a scale of -5 to 5 . The evaluation was done in relation to the current regulation on hygienic quality of drinking water [31].

Because of the great differences in flow rates between the springs, the highest score was given to the maximum flow rate of $11 \mathrm{l} / \mathrm{s}$, which is slightly higher than the flow rate of the first spring on Velika Sokolovica. Ratings were obtained by the formula:

$$
\mathrm{v}=5 \cdot\left(1-\frac{\mathrm{Q}_{\max }-\mathrm{Q}_{\mathrm{F}}}{\mathrm{Q}_{\mathrm{M}}}\right)
$$

...where $\mathrm{v}$ is rating, $\mathrm{Q}_{\max }$ is maximal flow rate $(\mathrm{l} / \mathrm{s})$, and $\mathrm{Q}_{\mathrm{F}}$ is flow rate of a spring $(1 / \mathrm{s})$.

Chemical and microbiological parameters were evaluated according to the following principle: on a scale of 0 to 5 , maximum allowable concentrations, i.e., values of the examined parameters, had a rating of 0 , and as parameters had a lower value they received a higher rating. Thus the value 0 received a rating of 5 , which in the case of chemical parameters represents an absolute ideal of pure water, and it is pointless for drinking water, but it is justified in this case of oligomineral water. Values below the maximum permissible concentrations were evaluated based on the degree of deviation from the permitted maximum, according to the following formula:

$$
\mathrm{V}=5 \cdot \frac{\mathrm{C}_{\max }-\mathrm{C}_{\mathrm{P}}}{\mathrm{C}_{\max }}
$$

...where $\mathrm{C}_{\max }$ is maximum allowable concentration, i.e., content, and $\mathrm{C}_{\mathrm{P}}$ is current concentration.

If the parameter values were higher than the maximum permitted, the ratings, in that case negative, were obtained by the inverse formula:

$$
\mathrm{v}=5 \cdot \frac{\mathrm{C}_{\max }-\mathrm{C}_{\mathrm{P}}}{\mathrm{C}_{\mathrm{P}}}
$$

An exception from this grading principle was the $\mathrm{pH}$ value, for which the permitted range is 6.5 to 8.5 , with the average value of 7.5. Within the allowed limits, $\mathrm{pH}$ values were evaluated based on the distance from the average value toward minimum or maximum:

$$
\mathrm{v}=5 \cdot(1-|\overline{\mathrm{pH}}-\mathrm{pH}|)
$$

... where is the average $\mathrm{pH}$ value, i.e., the middle ground between the minimum and maximum allowable values, and $\mathrm{pH}_{\mathrm{p}}$ is the current $\mathrm{pH}$ value.

The values of $\mathrm{pH}$ outside the permitted range, i.e., below the minimum, were evaluated according to the following formula:

$$
\mathrm{v}=5 \cdot \frac{\mathrm{pH}-\overline{\mathrm{pH}}}{\overline{\mathrm{pH}}}
$$

According to this formula, the negative ratings to -5 were given.

As for the grading of biological parameters, i.e., living organisms in the water, although for them there are no precise criteria anywhere in the world, based on the recommendations of the World Health Organization stating that their presence in drinking water is undesirable, ultimately for aesthetic reasons their absence from the water was taken as the ideal state. In order to enable the evaluation, the acceptable maximum was approximated as $1 \mathrm{U} / \mathrm{hl}$, and the evaluation was done by the following formula:

$$
\mathrm{v}=50 \cdot\left(1-\frac{\mathrm{B}_{\mathrm{F}}-\mathrm{B}_{\mathrm{I}}}{\mathrm{B}_{\mathrm{F}}}\right)
$$

...where $B_{F}$ is biological content of the spring and $B_{I}$ is approximated acceptable maximum.

Since on a scale of 0 to 5 very low marks, to the order of magnitude up to $10^{-2}$ were obtained, to increase the significance of the share of biological ratings in the overall evaluation, the deviation from the maximum was multiplied by 50 instead of 5 . The results of evaluation are shown in Tables 7 and 8 .

The average ratings based on all parameters showed that the first three springs of the Ribna and both Velika Sokolovica springs were relatively equal when it came to flow rate and quality, and the fourth and fifth springs of the Ribna were inferior to them. The average ratings on the basis of the chemical and microbiological parameters of water after sitting in bottles, on the basis of which it was possible to make a comparison with Vlasinska Rosa, showed that the first four Ribna springs and the second Velika Sokolovica spring were superior to the others. We saw that Vlasinska Rosa with negative marks was worse than the springs with the worst quality among these two sources.

Although it seems that the microbiological quality of the Jastrebac Mountain spring water could be the biggest problem in the process of bottling, it could be overcome by ultraviolet disinfection of water in the already sealed bottles. The biggest problem, in fact, could be a low $\mathrm{pH}$ value which, due to the silica surface (i.e., very low hardness), ranges under and around the lower limit of 6.5.

Anyway, in order to select the most appropriate springs for bottling, it is necessary to do a comprehensive physical 
Table 7. Ratings on springs and Vlasinska Rosa according to groups of parameters.

\begin{tabular}{|c|c|c|c|c|c|c|}
\hline \multirow{3}{*}{ Spring } & & \multicolumn{5}{|c|}{ Ratings } \\
\hline & & \multirow{2}{*}{ Flow rate } & \multirow{2}{*}{$\begin{array}{l}\text { Chemical } \\
\text { parameters }\end{array}$} & \multicolumn{2}{|c|}{ Microbiological parameters } & \multirow{2}{*}{$\begin{array}{l}\text { Biological } \\
\text { parameters }\end{array}$} \\
\hline & & & & in situ & After standing & \\
\hline \multirow{5}{*}{ RIBNA RIVER } & 1 & 0.62 & 3.89 & 4.88 & -1.13 & 0.96 \\
\hline & 2 & 0.65 & 3.87 & 4.86 & -1.17 & 0.47 \\
\hline & 3 & 0.08 & 3.96 & 4.87 & -0.40 & 0.10 \\
\hline & 4 & 0.02 & 3.70 & -1.45 & -1.12 & 0.02 \\
\hline & 5 & 0.01 & 3.48 & -1.41 & -1.56 & 0.01 \\
\hline \multirow{2}{*}{$\begin{array}{c}\text { VELIKA } \\
\text { SOKOLOVICA }\end{array}$} & 1 & 4.89 & 4.08 & 3.90 & -3.11 & 0.04 \\
\hline & 2 & 0.39 & 4.08 & 3.55 & 0.10 & 0.05 \\
\hline \multicolumn{2}{|c|}{ VLASINSKA ROSA } & - & 3.93 & - & -4.75 & - \\
\hline
\end{tabular}

and chemical analysis that includes the parameters of water such as radioactivity, toxic metals, and metalloids, and organic pollutants $[4,32-33]$.

\section{Conclusions}

The need for safe drinking water in Serbia is increasing because of the increasing pollution of natural and artificial sources, as well as due to the results of analysis of existing bottled water in the Serbian market, which often do not meet the standards set for drinking water. Therefore, the need for new sources is growing. As potential sources of water for bottling, the four sources on Jastrebac Mountain in central Serbia have been found and investigated. These are: Velika Ravan (two springs), Majorova Česma (one spring), Ribna River (five springs), and Velika Sokolovica (two springs).

Table 8. Average marks of springs and Vlasinska Rosa.

\begin{tabular}{|c|c|c|c|}
\hline \multicolumn{2}{|c|}{} & \multicolumn{2}{|c|}{ Marks } \\
\cline { 3 - 4 } \multicolumn{2}{|c|}{ Spring } & All & $\begin{array}{c}\text { Chemical and } \\
\text { microbiological } \\
\text { parameters } \\
\text { paramets after } \\
\text { standing }\end{array}$ \\
\hline \multirow{4}{*}{ RIBNA RIVER } & 1 & 1.84 & 1.38 \\
\cline { 2 - 4 } & 2 & 1.73 & 1.35 \\
\cline { 2 - 4 } & 4 & 1.72 & 1.78 \\
\cline { 2 - 4 } & 5 & 0.11 & 1.29 \\
\hline VELIKA & 1 & 1.96 & 0.96 \\
\cline { 2 - 4 } SOKOLOVICA & 2 & 1.59 & 0.49 \\
\hline VLASINSKA ROSA & - & 1.97 \\
\hline
\end{tabular}

The results of the analysis showed the following:

- The springs of Velika Ravan contained suspended solids, which are not permitted by the Regulations. Also, microbiological quality of water from these springs wasn't satisfactory because of the presence of the indicators of faecal contamination as well as the excessive content of the total count of aerobic mesophilic bacteria, especially in the first spring (Velika Ravan 1). In addition, the water from Velika Ravan 1 spring had a turbidity slightly above the allowed excessive content of iron and organic compounds as $\mathrm{KMnO}_{4}$ consumption, as well as a significant presence of fungi. Consequently, the springs on Velika Ravan were excluded as being a possibility for bottling.

- The Majorova Česma spring contained suspended solids and had a low $\mathrm{pH}$ value. Depending on the method, there was the excessive total count of bacteria. Therefore, this spring cannot be taken into account for bottling.

- The values of the examined parameters, as well as their ratings, showed that the Ribna River springs (especially the first three springs) and both springs of Velika Sokolovica were of exceptional quality. After standing in the bottles, the water from these springs was significantly better compared the commercially bottled Vlasinska Rosa. Based on this, it can be concluded that the first three Ribna River springs and both Velika Sokolovica springs could be taken into consideration for bottling after more extensive examination.

\section{Acknowledgements}

This study is a part of project TR 31001, financially supported by the Ministry of Education, Science, and Technological Development of the Republic of Serbia. 


\section{References}

1. EFSA. Scientific opinion on dietary reference values for water. European Food Safety Authority (EFSA) Journal, 8 (3), 1459, 2010.

2. CODEX. Recommended International Code of Practice Number 48 Code of Hygienic Practice for Bottled/Packaged Drinking Waters. Rome: Codex Alimentarius Comission.

3. WHO. Guidelines for drinking water quality. Fourth edition, World Health Organization, Geneva, Switzerland, 2011.

4. APHA AWWA WEF. Standard methods for the examination of water and wastewater. Washington, DC: American Public Health Association, American Water Works Association, Water Environment Federation, 2012.

5. SENIOR D.A.G., DEGE N.J. Technology of bottled water. $2^{\text {nd }}$ ed., Ames, Iowa, Blackwell Pub, 2015.

6. HERATH A.T., ABAYASEKARA C.L., CHANDRAJITH R., ADIKARAM N.K.B. Temporal variation of microbiological and chemical quality of noncarbonated bottled drinking water sold in Sri Lanka. Journal of Food Science, 77 (3), 160, 2012.

7. RODWAN J. Bottled water 2011: The recovery continues. US and International Development Statistics, New York: Beverage Marketing Corporation, 2011.

8. SVAGZDIENE R., LAU R., PAGE R.A. Microbiological quality of bottled water brands sold in retail outlets in New Zealand. Water Science and Technology: Water Supply, 10 (5), 589, 2010.

9. AHMAD M., BAJAHLAN A.S. Quality comparison of tap water vs. bottled water in the industrial city of Yanbu (Saudi Arabia). Environmental Monitoring and Assessment, 159 (1-4), 1, 2009.

10. BANDARA D.M.B., CHANDRAKUMARA D.P.S. A binary logistic regression analysis on the demand for bottled water in the city of Colombo. International Journal of Multidisciplinary Research and Development, 2 (11), 428, 2015.

11. KASSENGA G.R. The health-related microbiological quality of bottled drinking water sold in Dar es Salaam, Tanzania. Journal of Water and Health, 5 (1), 179, 2007.

12. NUNES M., FUZIHARA T.O. Microbiological evaluation of bottled mineral waters and marketed in the $\mathrm{ABC}$ region, SP. Hygiene Alimentar, 25 (200/201), 195, 2011.

13. RAJ S.D. Bottled water: How safe is it? Water Environment Research, 77 (7), 3013, 2005.

14. VARGA L. Bacteriological quality of bottled natural mineral waters commercialized in Hungary. Food Control, 22 (3-4), 591, 2011.

15. FRANCISCO J.P.S. Why households buy bottled water: a survey of household perceptions in the Philippines. International Journal of Consumer Studies, 38 (1), 98, 2014.

16. IBWA. Types of water - bottled. The International Bottled Water Association, Alexandria, Virginia, USA. Available online: http://www.bottledwater.org/types/bottled-water (accessed on 83 2017).

17. STOJANOVIĆ M., ĆIRIĆ S. The hygienic safety of drinking water from central water supply system of the Municipality of Leskovac. The First International Congress "Ecology, health, work, sport", Proceedings I, II, Banja Luka, Republic of Srpska, 397, 2006 [In Serbian].
18. PANT N.D., POUDYAL N., BHATTACHARYA S.K. Bacteriological quality of bottled drinking water versus municipal tap water in Dharan municipality, Nepal. Journal of Health, Population and Nutrition, 35 (17), DOI:10.1186/ s41043-016-0054-0, 2016.

19. ĆIRIĆ S., PETROVIĆ O. Comparison of cultural methods on bacterial recovery in source water for water supply. Fresenius Environmental Bulletin, 18 (11a), 2203, 2009.

20. ĆIRIĆ S., PETROVIĆ O., MILENKOVIĆ D. Low-nutrient R2A medium in monitoring microbiological quality of drinking water. Chemical Industry \& Chemical Engineering Quaterly (CI \& CEQ), 16 (1), 39, 2010.

21. MOAZENI M., ATEFI M., EBRAHIMI A., RAZUJOO P., VAHID DASTJERDI M. Evaluation of chemical and microbiological quality in 21 brands of Iranian bottled drinking waters in 2012: a comparison study on label and real contents. Journal of Environmental and Public Health, Vol. 2013, Article ID 469590, DOI: 10.1155/2013/469590, 2013.

22. MBATA T.I., OGIEHOR S.I., OBELEAGU M.N. Isolation of filamentous fungi from Yardenit-Baptismal site on the Jordan River. Sudanese Journal of Public Health, 3 (4), 173, 2008.

23. DOMSCH K.H., GAMS W., ANDERSON T.H. Compendium of soil fungi. Volume 1, Academic Press, London, UK, 1980.

24. BARNETT H.L., HUNTER B.B. Illustrated genera of Imperfect Fungi. 4th ed. Burgess, Minneapolis, MN, pp. 218, 1986.

25. FALCONE-DIAZ M.F., VAZ-MOREIRA I., MANAIA C.F. Bottled mineral water as a potential source of antibiotic resistant bacteria. Water Research, 46, 3612, 2012.

26. DURANCEAU S.J., EMERSON H.P., WILDER R.J. Impact of bottled water storage duration and location on bacteriological quality. Interantional Journal of Environmental Health Research, 22 (6), 543, 2012.

27. ZEENAT A., HATHA A.A.M., VIOLA L., VIPRA K. Bacteriological quality and risk assessment of the imported and domestic bottled mineral water sold in Fiji. Journal of Water and Health, 7 (4), 642, 2009.

28. PINDI P.K., YADAV P.R., KODAPARTHI A. Bacteriological and physico-chemical quality of main drinking water sources. Polish Journal of Environmental Studies, 22 (3), 825, 2013.

29. EL-SALAM M.M.M.A., EL-GHITANY E.M.A., KASSEM M.M.M. Quality of bottled water brands in Egypt Part II: Biological water examination. The Journal of the Egyptian Public Health Association, 83 (5-6), 467, 2008.

30. ĐUKIĆ D., ĐORĐEVIĆ S. Natural Microbiology. Stylos, Novi Sad, Serbia, pp. 179, 2005 [In Serbian].

31. Official Gazette of the SFRY No. 42/1998. Regulation on hygienic quality of drinking water. 1998 [In Serbian].

32. ISO. ISO/DIS 10704. Water quality - Measurement of gross alpha and gross beta activity in non-saline water - Thin source deposit method. International Organization for Standardisation, Geneva. 2008.

33. ISO. ISO 13161. Water quality - Measurement of polonium 210 concentration activity in water by alpha spectrometry. International Organization for Standardisation, Geneva. 2011. 